\title{
4 \\ Misfortune, witchcraft, and the will of God
}

An obvious corollary to a belief in witches is the perception that certain kinds of recognizable injuries or misfortunes are due to witchcraft, and it is clear from the sources that many people in medieval Europe were, at times, prepared to accept certain kinds of misfortunes as the result of witchcraft or harmful magic. ${ }^{1}$ Not everyone, however, understood the relationship between magic and its effects in the same way. For unlettered peasants and townsfolk - for everyone, in fact, but a small elite of educated men and women - the relationship between "magic" and its intended result was probably a straightforward case of cause and effect, in which the witch or sorcerer who deployed occult powers for harmful ends was as much responsible for the resulting injuries as was a person wielding a knife with murderous intent.

For the theologically more sophisticated elite, however, the relationship between a witch, her magic, and associated injuries, was fraught with difficulties of considerable complexity. From their perspective, since the witch could not be the immediate cause of magical harm, both because a demon actually effected the injury, and because the witch had no power to compel the demon to do her bidding, the extent to which witches were actually culpable for the injuries inflicted by demons in their name was questionable. The matter was further complicated by the fact that demons could act only with the permission of God. Hence, if demons acted merely in accordance with divine will, why should either the witch or the demon be blamed for the outcome? And why, too, should God have chosen to give the witch or the demon free latitude to carry out magical assaults of their own volition in the first place? To endorse witch persecution, educated Christians had to answer these questions in such a way that the witch would emerge as the efficient cause of worldly misfortune. When she was not, when either a witch's power to cause harm or her moral responsibility for it were called into question, latemedieval writers tended to dismiss the dangers posed by witchcraft. The widespread skepticism about the reality of witchcraft in the late Middle Ages 
responded precisely to this concern that the belief in witchcraft as, say, Institoris and Sprenger understood it, was a gross affront to both the omnipotence and justice of God. To understand the alternative explanations for magical harm and witchcraft propounded by Institoris and Sprenger and their colleagues, we need therefore first to take a more general look at medieval conceptions of magic and misfortune.

There was never a single, universally applicable explication of misfortune in the Middle Ages. Instead, circumstances dictated the conceptual model appropriate to the beliefs of the observer. In any given instance, a substantial number of interpretations were possible, witchcraft being one and never the most prevalent. Misfortune, as Rodney Needham observes, can be explained in any number of ways:

If misfortune strikes, you can blame an inscrutable god or capricious spirits; you can concede that it is the just retribution of your sin, or else that it is the automatic consequence of some unintended fault; you can put it down to bad luck ..., or more calculating you can ascribe it to chance. ${ }^{2}$

During the Middle Ages, all of these possible explanations for sudden misfortune (with the possible exception of chance) were available alongside witchcraft, making for overlapping and competing patterns of considerable complexity.

For instance, the Franciscan chronicler Salimbene de Adam reported that in 1287 a large crowd of Pisans had gathered in a square to watch a great bell being hung. Then, "just as it was being lifted off the platform, it tipped over and fell to the ground. But it injured no one, save for a young man whose foot it cut off." ${ }^{3}$ Human life was full of such unexpected mischances, but to Salimbene, as to all knowledgeable clerics, it was misleading to call such an unfortunate accident an "evil," for God had so ordered his creation that events which were injurious or harmful from one perspective always contributed to some ultimate good. Men might be made to suffer either toward some inscrutable end known only to God, or for their own just punishment and correction as, it so happened, in the case of the maimed youth:

For he had once kicked his father with this foot and therefore did not escape with impunity. Thus, by a misfortune of this kind, God demonstrated his justice. ${ }^{4}$

For Salimbene, the cause of the young man's punishment lay directly in his sin. Such an explanation did not necessarily rule out subsidiary factors - the workmen may have been careless, the platform may have been unstable, or a demon may have pushed over the bell - but it did establish why this man was harmed and no other, and explained the precise nature of his injuries. 
The basis for Salimbene's understanding of this incident was provided by Augustine's thorough delineation of the problems posed by misfortune and material evil in the world. According to Augustine, divine providence dictated all the injuries suffered by man, although for a number of potentially quite different reasons. Some punishments were purificatory, intended to "discipline and correct" the sinner and to guide him along the path to salvation. All other misfortunes and injuries, Augustine believed, were

imposed either in retribution for sins, whether past sins or sins in which the person so chastised is still living, or else to exercise and to display the virtues of the good. ${ }^{5}$

God did not, however, administer correction directly, but relied instead upon the agency of men and of angels, both evil and good. Through them, all were made subject to the consequences of Adam's sin; even the innocent were condemned to suffer the countless miseries of human life due simply to their own fallen natures and life in a now fallen creation. For Augustine, storms, tempests, earthquakes, fire, flood, famine - in short the entire gamut of possible calamities - were "not directed to the punishment of the wickedness and lawlessness of evil man, but are part of our common condition of wretchedness." Hence, even infants newly baptized and free from any possible culpability had to suffer disease, accidents, and even the assaults of demons, because they were doomed to live in a world made dangerous by the sins of their fathers. God did not, however, harm the innocent in any absolute sense, despite the physical miseries he might inflict: true, demons were allowed to torment innocent children, but, "we must never think that these sufferings can do them real harm, even if they grow so severe as to cut off the soul from the body," since death would merely hasten the journey of blameless souls to paradise. ${ }^{7}$

Augustine argued that although divine providence was the ultimate cause of misfortunes and injuries, only human sin was to blame. To look outside one's self, and place responsibility for catastrophes on fallen angels or evil men, was both misguided and, at worst, a dishonest evasion of responsibility. Instead, when good Christians considered the suffering wrought by some sudden or unexpected injury,

First, they consider in humility the sins which have moved God's indignation so that he has filled the world with dire calamities. And although they are free from criminal and godless wickedness, still they do not regard themselves as so far removed from such wrongdoing as not to deserve to suffer from temporal ills which are the recompense for $\sin .^{8}$

This did not mean, of course, that ill-doers should not be punished, still less that criminals were not culpable for their crimes, since they freely willed the 
evils they committed. Augustine differentiated, however, between the crimes of men and the seemingly random hazards of the world. In the case of the latter, it was pointless to rail against the angel that carried out God's will, whether evil or no, since never in the least degree could they exceed the freedom allowed them by God.

Augustine's interpretation of misfortune as the collective product of God, demons, and human sin, was echoed repeatedly during the Middle Ages. Isidore of Seville, for example, writes that "When God visits his wrath he sends apostate angels as his ministers, but limits their powers, so that they do not do the evil they wish." Similarly, Gregory the Great reminds readers of his Moralia in Job that

You see that one and the same spirit is both called the Lord's spirit and an evil spirit; the Lord's, that is, by the concession of just power, but evil, by the desire of an unjust will, so that he is not to be dreaded who has no power but by permission; and, therefore, that Power is the only worthy object of fear, which is when It has allowed the enemy to serve the purpose of a just judgment. ${ }^{10}$

And so, too, in the tenth century, Rather of Verona comments that the power to punish or correct belonged to God alone, and only "those who are deceived by this power ascribe it to the deceiver himself." ${ }^{11}$ Thus all punishment, all misfortune, all the evils of the world were ultimately the work of God, who infuriated the devil by turning his malice to good ends: such was the traditional Christian interpretation of misfortune, until the end of the thirteenth century, when several factors conspired to modify this understanding, and to shift responsibility for misfortune away from God and towards his ministers.

Of course, monastic writings had long been filled with demons of an appearance quite different from those of the theologians and canonists. Athanasius, for example, represented the life of St. Anthony as a continuous and quite personal struggle with the devil. Temptations rose to torment the saint not as a consequence of his fallen nature, but from the machinations of the fiend, whose "commission" it was in every case to waylay pious youth. ${ }^{12}$ When temptation failed, the devil resorted to more physical methods and assaulted the saint with blows and fearful visions of wild beasts. Yet, although Anthony lived with daily and direct intercourse with demons, Athanasius always imparts the clear sense that the saint's victory was inevitable and that the devil was powerless before God: Anthony mocks the demons that assail him, telling them that "it is a sign of your helplessness that you ape the form of brutes," and that they tire themselves needlessly, "for faith in our Lord is a seal to us and a wall of safety." ${ }^{13}$

Anthony's career provided a paradigm for the monastic life that was replicated faithfully many times, both in the vitae of saints and in the experiences 
of humbler monks. Like Anthony, monks conceived of themselves as constantly beset by temptations orchestrated by the devil, for whom the purity of their lives acted as irresistible bait. Consistently referring to these inner struggles in terms of combat and battle with an exterior foe, their war stories are inhabited by aggressive, formidable opponents, who, if ultimately answerable to divine will, had to appear self-willed and independent for cogent dramatic reasons. ${ }^{14}$ Numerous examples reminded monks constantly that they lived in an environment in which the power of Satan was incessantly at work, in which any stray thought or mischance was a manifestation of the devil's immediate presence.

It was possible, indeed easy, for this view of the world to be taken to extremes. Peter Damian tells of a monk named Marinus, who daily encountered the devil in various forms: he appeared as an angel of light to trick Marinus into minor sins, and, in less pleasant guise, the devil joined mockingly in the celebration of opus Dei.${ }^{15}$ Still more remarkable was the case of Ricalmus, a thirteenth-century Carthusian monk and the abbot of Schönthal, who, by special grace, could see the normally invisible demons that swarmed about him, and who recorded his experiences for posterity. Ricalmus' world was filled with demons who were responsible not only for interior temptation but also for all the other petty annoyances which distracted him from proper concentration on the divine office:

The devils, without a particle of respect for his character or his years used to call him a "dirty hairless rat;" afflicted him with bloating of the stomach and with diarrhea, with nausea and with giddiness; so benumbed his hands that he could no longer make the sign of the cross; caused him to fall asleep in the choir and then snored so as to make the other monks think that it was he who was snoring. They would speak with his voice, make him cough, force him to expectorate, hide themselves in his bed and stop his nostrils and his mouth so that he could not breathe, compel him to urinate, or bite him like fleas; and if, endeavoring to fight off drowsiness, he exposed his hands to the cold air, they would draw them back under the coverlet and warm them again ... All the noises that proceed from the human body, all those that issue from inanimate things are simply the work of evil spirits, except the sound of bells, which is the work of good spirits. Hoarseness, toothache, partial loss of voice, errors committed in reading, the whims and impulses of the sick, gloomy thoughts, and the thousand petty accidents of the body and the life of the soul are due to diabolic powers. ${ }^{16}$

Admittedly, Ricalmus is an extreme case. For one thing, it is painfully apparent in his account that diabolic power has become an excuse for embarrassing personal lapses; for another, his is an altogether dualist world, permeated by the forces of darkness. Yet the assumptions about the role of demons in this 
world that lay behind his tale were readily understood, and accepted, by his peers.

Provided that such accounts were confined to a monastic milieu, it was possible to interpret them quite traditionally, as examples of an old and respected genre of narrative. With the twelfth century, however, and especially with the expansion of preaching that followed on the heels of the Fourth Lateran Council, many of these stories were distributed in sermons further afield, where they may well have helped to disseminate the image of a powerful, self-willed, and physically concrete devil, operating with minimal divine oversight. ${ }^{17}$ Moreover, in some of these exempla, which competed in sermons side by side with more edifying accounts of divine judgment, monastic demons merged with the destructive spirits of folk tradition to emphasize diabolic responsibility for misfortune at the expense of the divine. ${ }^{18}$

To take one example, the Dominican preacher Thomas of Cantimpré wrote in 1258 that during a demonically inspired storm, the vines of a notorious usurer were left intact, and that aerial demons were even heard to cry out, "Cave, cave," when an overzealous member of their company approached his lands too closely. ${ }^{19}$ Thomas intended, of course, to illustrate that material prosperity is no sure indication of spiritual merit as well as the diabolic nature of usury, but in the process he created a group of free-wheeling demons, to all appearances acting very much of their own accord. Nor were such tales repeated only in sermons for the laity. Gerald of Wales told essentially the same anecdote but in a rather different context in his Itinerarium Kambriae. ${ }^{20}$ In Gerald's version, a terrible storm had one evening destroyed the crops of a Cistercian monastery, but had spared the fields of a neighboring knight, with whom the monks had been embroiled in a protracted boundary dispute. The knight insolently and publicly proclaimed that by the just judgment of God this misfortune manifestly demonstrated that he was in the right. The abbot would have none of this, however, and replied that on the contrary the calamity was simply in accord with the usual practice of demons, who spared their friends and afflicted their enemies. The account is interesting because here we have two competing interpretations of misfortune set side by side, although, doubtless, had the situation been reversed the witty abbot would have been quick to seize the alternative explanation. Yet the ease with which demons are transformed from the scourge of sinners to the enemies of the just is striking. Nor are these demons simply straw men to be overcome by Christian faith, even that of pious monks; they are instead formidable foes, whose assaults must be endured.

Neither of these authors would have seen anything particularly incongruous in his respective exempla, since he would have interpreted them with a similar understanding of the relationship between God, sin, and misfortune. 
Of course that is not to say that less learned folk would necessarily have grasped the unspoken consistency among them, but that while the clergy endorsed a thoroughly Augustinian demonology there was a limit to how much freedom they allowed the devil. Although demons in exempla might appear to act freely, their behavior was theoretically under close divine supervision. But even as the demons in ecclesiastical narratives marshaled their strength, scholastic theologians were setting about to refine and systematize their relationships with God, just as they were doing with demonic origins and nature. The result of this investigation was a marked loosening of the bonds by which the devil was confined and controlled, and a kind of theological sanction for enhanced diabolic power and responsibility.

The contribution of Thomas Aquinas to the problem of misfortune lay in two principal areas: the causes of evil and the extent of divine supervision of demons. Of these, the most basic and abstract was his discussion of the cause of evil, which was in turn based on two fundamental sets of ideas. The first, taken from Augustine and ultimately Plato, assumed that evil was a species of privation, the lack of some native or otherwise appropriate good; the second was the Aristotelian theory of fourfold causation - material, formal, efficient, and final. ${ }^{21}$ In short, Aquinas argued that God, who was wholly good, could not be the cause of any evil of any kind whatsoever, except accidentally, because privation could only result from a deficient cause which could not be God. ${ }^{22}$ Certainly God permitted evils to happen, because they were necessary to the goodness of his creation, but he did not in any sense cause them to happen. Even if his justice demanded that a man die, God was only the cause of justice, and not of death. ${ }^{23}$ But since, as Aquinas clearly says, all evils must have a cause ("omne malum aliqualiter causam habeat"), whence comes evil? The answer is that one simply has to look for the last defective cause in the chain of efficient causes; to use Aquinas's example, when a boat sinks due to the carelessness of a sailor, that particular evil may be traced back only to the sailor in whom the defect lay and not to God.

This line of analysis extended to the injuries caused by demons. Certainly, everything that demons did, they did only with the permission of God, but it was much more difficult to say exactly what this permission meant, and how and why it was granted. For Aquinas, the key consideration was the difficult distinction between divine permission and divine will. Demons attacked men in two ways: first, by instigating them to sin through temptation, and, second, more directly through punishment. God ordered both kinds of attack for the higher good, but, while God's just judgments sent demons to punish certain men, temptation was sometimes permitted even though God did not will it. ${ }^{24}$ But for this distinction to have meaning, God's permission must be a more generous form of oversight, a kind of passive adjunct to God's active will; hence Aquinas's demons appear to have had much 
more latitude over the manner and subjects of temptation than they did over direct punishment.

Still worse for unfortunate sinners, in Aquinas's mind, temptation could lead directly to punishment. In his discussion of the effects of Christ's passion, he explains that the devil may legitimately be said to have power over mankind:

To the first point it should be said that the devil is not found to have had power over people to such a degree that he could harm them without God's permission, but that he was justly permitted to injure people whom by tempting he had induced to give consent. ${ }^{25}$

If the devil, in other words, was allowed to tempt a man of his own choosing, and if that man succumbed, the devil might also be allowed to punish him, not because God willed it, but because by sinning the man had placed himself in the devil's power. In this way, Aquinas allowed a considerable expansion of both the devil's power to make trouble and his responsibility for it. To be sure, it was not that the devil had ceased to be God's slave, or that he was no longer ultimately answerable to divine will; rather, Aquinas perceived the nature of divine oversight to be more flexible and more remote.

By the end of the thirteenth century, popular beliefs, monastic narratives, and theological speculation had thus converged around a more autonomous conception of the devil's power. Contributing to this trend, perhaps, were also anxieties felt by the Church about diabolically inspired heresy, as well as the widespread dissemination of dualist beliefs. To many people, it seemed as if God were no longer so intent on the micro-management of his demons, and that now demons held a correspondingly greater share of the responsibility for worldly misfortune. ${ }^{26}$ Thus, especially after Aquinas had seemingly exculpated God of any share in the actual production of misfortune, late-medieval scholarly and ecclesiastical interest tended to focus on demons as the efficient cause of misfortunes in the world, and it was within this context that magic was understood.

While the devil was still constrained closely by divine will and defeated easily by Christian faith, malign magic was a relatively minor concern, for while neither Augustine nor his successors ever denied the existence of harmful magic, the restrictions they placed upon the devil's freedom of operation placed serious limitations upon its use. ${ }^{27}$ Indeed, a battery of arguments, all of which depended ultimately upon the power and justice of God, opposed the need for serious persecution of sorcerers.

In the first place, to allow malefici to usurp the administration of divine justice would be unseemly at best. As Rather of Verona remarked irritably, if you believed that the world was full of witches flying around at night, and that misfortunes were due to their evil magic, what became of the lessons of Job? 
Who I say, of people being deceived like this, seeing a man being whipped like the admirable Job... would urge him to say, and would believe it justly said, "The Lord gives, the Lord takes away, as the Lord pleases, so it is done?" No, he would ascribe it to wicked angels or to certain pitiable men and would urge that some controller - or "rainmaker" as he is called - be summoned and begged with gifts to deign to cure it . . For not to mention the loss of such glory as was Job's, would they not do this about a mere trifle, a penknife or a shoelace. $^{28}$

Since demons cannot do any harm without the Lord's direct and explicit permission, the victim of a magical attack would be better advised to spend his time searching his own conscience rather than ferreting out witches. Rather's position was simple, clear, and unmistakably Augustinian: misfortune came ultimately from God; and so, like Job, we should bear it with patience.

To most educated Christians of late antiquity, magic was a subspecies of pagan idolatry, and just as God permitted demons to impersonate pagan deities, he also occasionally allowed demons to give efficacy to magical operations. In both cases, his motive was the same: to lead the souls of superstitious operators to perdition: hence, the principal victims of magic were the magicians themselves, who, like pagans, properly could be punished, but, better still, should be converted. ${ }^{29}$ Denigrating magicians as virtual pagans also led early theologians to be skeptical of their powers. Indeed, again according to Augustine, much of what magicians appeared to do was simply an illusion of the devil, and Augustine invariably referred to magic as a lie, a deceit, or a deception. ${ }^{30}$ Superstitious diviners, he claims, were "subjected to illusion and deception as a reward for their desires"; the supposedly benign magic of theurgy was "all the invention of lying demons." "1

From this perspective, all works of the devil were kinds of deceit: magic, superstition, paganism, were all, by this way of thinking, at bottom empty of substance; they were delusions. This was a tradition enshrined in a number of influential early-medieval canons, most notably the canon Episcopi, but also a decision of the Council of Braga that demons could not control the weather. ${ }^{32}$ Pastoral concern to limit the scope of demonic power kept it alive. Hence early-medieval penitentials denounced those who believed that enchanters were able to summon storms, or use demons to sway the people's minds, or that some women could magically inspire love and hatred, or steal one's goods. ${ }^{33}$ In precisely the same way, German penitentials of the late fifteenth century continue to condemn those who believe in the reality and efficacy of weather-witches, werewolves, broomstick-riders, "and other such heathen, nonsensical impostures." 34

Although this conception of magic would have a lasting influence upon ecclesiastical thinking, it was never fully accepted. On the one hand, a popular 
belief in the efficacy of magic was simply too strong to be dispelled. Augustine himself, for instance, gave grudging credence to "that pernicious and abominable science by which, as the tale goes, one man's crops could be transferred to another's land." ${ }^{35}$ On the other, most authors acknowledged that, given their natural powers, demons could do much more than work mere illusions. Thus in his little treatise, De Magicis Artibus, Hrabanus Maurus (d. 857) argued that magic per se had no power at all, unless the magician had made a pact with a demon and unless God in his wisdom permitted the demon to act in accordance with the magician's wishes. ${ }^{36}$ This being the case, however, real effects could follow upon magical operations. When scholastics analyzed the devil's nature, irrespective of the question of divine permission, logic compelled them to enlarge considerably the range of his powers: simply by virtue of their angelic natures, demons could confound the senses, create illusions, delude the mind, cause bodily infirmity, illness and death, control the weather, move with preternatural speed, transport physical objects, and so on. ${ }^{37}$

Yet even so, traditionally minded writers insisted that God would never permit demons to use these powers freely. It would, for one thing, be dangerously impractical. In the thirteenth century, William of Paris allowed that harmful magic was effective occasionally because demons were permitted sometimes to chastise men in this way, but he did not permit his readers to suppose that this happened often:

For when it has become clear to you how much care there is in the wisdom and goodness of the creator for people and human affairs, it will plainly dawn on you that he does not commit the government of them to images, or to stars, or to the luminaries, or even to the heavens, nor in any way expose them to the will of magicians or acts of harmful magic. ${ }^{38}$

To William, this was a matter of common sense, "For no beautiful woman would remain undefiled, no prince and no magnate would remain safe, if demons were permitted to appear and to give satisfaction to the evil will of men." 39

William's argument reflects an ancient confidence in Christ's triumph over Satan; because magic was a tool and invention of the devil, his defeat logically gave his followers immunity. As Peter Brown puts it, "the Church was the community for whom Satan had been bound: his limitless powers had been bridled to permit the triumph of the Gospel; more immediately, the practicing Christian gained immunity from sorcery." ${ }^{\text {"40 }}$ Early medieval discussions of magic regularly took such protection for granted. For example, Isidore of Seville provided the Middle Ages with its standard exposition of magic in a vastly influential and much quoted précis of Augustine's views. According to Isidore, 
Magicians are those who are commonly called malefici [evil-doers] on account of the magnitude of their crimes. These persons excite the elements, disturb the minds of men, and without any draught of poison, with violence only through their incantations, they kill ... For having summoned demons they dare to boast that each destroys his enemies by the evil arts. And these men also make use of blood and victims, and often take the bodies of the dead ... and the blood of a cadaver is scattered to arouse [demons], for demons are said to love blood. And so, as often as necromancy is performed, water is mixed with gore so that by the color of blood they are more easily excited. ${ }^{41}$

Although Isidore grants that sorcerers could readily effect material harm through their magic, he makes it plain, following Augustine, that he speaks here of pagan magicians: his sources are Lucan, Vergil, and Varro, and he nestles "De magis" comfortably between "De Sibyllis" and "De paganis." When later commentators quoted this passage, they modified Isidore's text to adapt his meaning to a fully Christian society. Burchard of Worms, Ivo of Chartres, and Gratian all included variations on Isidore's definition of magicians in their collections of canons, although mistakenly attributing it to Augustine himself. Magicians, they reported, could excite the elements only with divine permission, and their magic could harm only those men "who have little trust in God." $" 42$

Just who these faithless men were, though, was not entirely clear. While Augustine and Isidore had conceived of magic as a kind of adjunct paganism, a scourge afflicting those who had not yet embraced Christianity, later writers viewed magical harm instead in more general terms as a punishment for sinners. This made perfect sense, since if, following Aquinas, demons could punish sinners of their own accord, they should equally have the power to work diabolic magic. In this vein Jacques de Vitry encouraged his readers to remember that,

In truth, diviners and witches are unable to harm those who are confessed and penitent, nor are they able to delude those who place their hope in God; they are accustomed, however, to delude sinners, because God permits this for the expulsion of sins. ${ }^{43}$

By the late Middle Ages, then, there was a substantial and authoritative body of opinion highly skeptical of the ability of magicians to inflict injuries as they wished. For many, this traditional view of magic and misfortune remained entirely sufficient: among the most spiritually inclined - those whose attention was focused single-mindedly upon the divine - harmful magic, like misfortune of any kind, was a matter of small concern since a man's fate lay wholly in the hands of God. Thus Henry Suso, a fourteenth-century German Dominican and mystic, enjoined his friends to embrace all suffering as a gift of God: 
A suffering man should remember [the martyrdom and glory of the saints] and rejoice that God has deigned, by means of suffering, to associate him with his dearest friends. ${ }^{44}$

Preachers, whose main concern was the spiritual welfare of laymen, likewise often took a traditionalist line, emphasizing the impotence of the devil before the omnipotence and goodness of God. Although finding forthright denials of magicians' power to harm the innocent is not so easy after 1300, still, preachers often spoke of magic in generally Augustinian terms, as a deceit or illusion and not the object of fear. ${ }^{45}$

Scholars trained in the via moderna, who in large part rejected the Thomist conception of the universe, were also generally little interested in the problem of witchcraft. Not viewing the sensible world as the lowest emanation of a unified hierarchical system, Nominalists tended to focus their investigation of physical, earthly effects on observable secondary causes. ${ }^{46}$ Without doubt, God was the first and final cause of all things, but because material effects could not be conceived as a direct expression of rational (and so comprehensible) divine thought, it was pointless to look to heaven for causes which could be found more easily and more reliably here on earth. ${ }^{47}$ Witchcraft, from this perspective, could never be a necessary cause of a given effect, because human and demonic (or angelic) realms were not deterministically linked. Nor could one of Ockham's followers ever arrive at an absolutely valid determination of witchcraft, because on purely epistemological grounds, one could admit a cause and effect relationship only if both terms were known; causation could never be determined only by effects. ${ }^{48}$ For these reasons, most latemedieval nominalists remained comparatively unconcerned by the physical dangers posed by witchcraft and seldom wrote witch-treatises. A rare exception was Samuel de Cassini, who, in the early sixteenth century, attacked the reality of witches' flight in conventionally nominalist terms. There was no cause, Samuel maintained, which produced an effect directly, except as "naturally ordained," meaning that the agent possessed the natural and intrinsic power to carry it out. ${ }^{49}$ Demons, furthermore, despite their powers of local motion, lacked the natural ability to move corporal bodies through the air; and, if they should by some chance happen to do so, the result, properly speaking, would be a miracle, and a miracle could never be the occasion for sin. ${ }^{50}$ Hence, Samuel concluded, the flight of witches was merely a delusion, and those who felt otherwise offended against both the omnipotence and the justice of God.

Even among demonologists, authors who embraced this more traditional view of divine oversight, and the consequent limitations on demonic power, the persecution of witches seemed less necessary, even when they accepted the reality of a devil-worshiping sect. Ulrich Molitor, for example, admitted 
that witches existed, and that they were deservedly punished for giving homage to the devil, but he also stressed that whatever else they might do, witches could not be in any sense the efficient cause of misfortune. While demons could, when God permitted, bring about worldly evils, "sometimes as punishment, for the correction of the wicked, sometimes as temptation, for the increase of merit, and sometimes as a foreshadowing of a future action of grace," witches themselves had nothing to do with any of this. ${ }^{51}$ Witches believed that they could bring about misfortune only because they were deluded by the devil. Storms, for instance, were caused by natural agencies, such as the movement of the stars or planets, or by demons if God willed it. In either case, though,

when [the devil] knows beforehand of a future calamity of this kind, he then stirs up the minds of Malckiesae mulieres, sometimes by persuading them himself; sometimes on account of envy, which such wicked women bear toward a neighbor, he inspires them to a deed of vengeance, as if he were teaching the women to provoke storms of this kind and disturbances of the air. ${ }^{52}$

There was no reason, then, to fear old women when they brewed potions or cast water into the air, because whatever calamity ensued was destined by divine providence to happen anyway. Maleficium was not, to Molitor, a visible and efficient sign of the devil, but a useless and meaningless gesture, designed only to impress and delude the simple-minded. ${ }^{53}$

Molitor's views were shared by other learned men. Around 1475, Jean Vincent, the prior of Les Moustiers, wrote a tract in which he argued that witches were deluded into accepting the destruction caused by the devil as their own. Witches, he writes, were those who believed that they were carried to the Sabbat by a demon, while they actually slept in their beds. At the Sabbat, they burned alive children taken from their mothers' breasts. But by his knowledge of causes, the devil could predict which children would sicken, which vines would wither, and where and when storms would strike. He suggested these things to the sleeping women, who then sincerely claimed responsibility for them when they occurred. ${ }^{54}$ More assertive yet was the famous Dominican reformer and theologian, Nicholas of Cusa. In a sermon on the pervasive belief in witches, Nicholas wondered why it was, if the devil had a free hand, that where faith in Christ and his saints was cultivated, the land was most blessed.

Where, however, men believe those maleficia to be done effectually, there more witches are discovered, nor can they be extirpated with fire and sword, because the more diligently this kind of persecution is carried out, the more the delusion grows. For persecution argues that the devil is more to be feared than God, 
and that he can heap up evils in the midst of evils, and so, at last, the devil, who is so feared, is sated and so his purpose is achieved. ${ }^{55}$

For this reason, and to spare the blood of innocents, Nicholas urged his auditors to abandon the fruitless persecution of old women and turn their minds instead to God, the real arbiter of their fate. ${ }^{56}$

To argue, on the contrary, that witches used their magic to cause harm freely, and that they were personally and immediately responsible for the injuries that ensued, required theorists to address the problem of divine permission. Simply to assert that all that witches did, they did with the permission of God, was insufficient. Though late-medieval demonologists seem endlessly to repeat the phrase, "with the permission of God," whenever they discussed the powers of witches and demons, almost as a polite gesture in the direction of divine omnipotence, the phrase explains nothing precisely because it could explain anything at all. As Petrus Mamoris points out, to say that something happened with divine permission is to state the patently obvious, "since there is nothing in the world which God does not permit, either good or evil." 57 Nor was God's wholesale grant of power to demons a palatable prospect: only a few authorities, such as the early-sixteenth-century witchtheorist, Vincente Dodo, went down this path.

Dodo, however, held that, with the permission of God, the devil was responsible for the flight of witches, their amazing transformations, and their malevolent magic, but that, "in consequence, divine permission is to be understood negatively." 58 That is, God permitted demons to do anything they pleased, provided he did not specifically prohibit it: Dodo maintained that God normally allowed all created beings, including demons, the free use of their natural powers, unless, as sometimes happened, he should intervene. In this, Dodo's argument was a logical extension of scholastic principles, but for most of his colleagues such a broad-ranging capitulation by the heavenly host was difficult to accept. Even in the Malleus God was not so passive; Institoris and Sprenger were careful to remind their readers that demons were merely agents, whom God employed to castigate sinners: "For God is accustomed to inflict the evils which are done for the exaction of our sins on earth, through demons acting as though they were his torturers." 59

Perhaps prompted by such difficulties, by the mid-fifteenth century, theorists had begun to explore an alternative explanation of magical harm. Because God allowed demons to lend efficacy to superstitious observances in order to punish the operator, so the argument ran, divine permission depended more upon the magician's sin than that of his victim. The theory probably had its genesis in statements such as that of the early-fourteenthcentury theologian, William of Ware, who declared that "magicians are unable 
to disturb the minds of good men who do not believe such things, but only the minds of infidels and evil men." ${ }^{" 60}$ Although perfectly orthodox and traditional, Ware's statement could easily be misinterpreted to mean that the efficacy of magic is dependent upon belief, and this is, in fact, precisely what one finds in a contemporary devotional treatise on the Ten Commandments, Robert of Brunne's Handlyng Synne. There, a witch explains to a bewildered bishop why he is unable to emulate her magic and animate her magic milking bag:

Ye beleue nat as y do:

wold ye beleue my wordys as y,

Hyt shulde a go, and sokun ky. ${ }^{61}$

In other words, if the witch is to be trusted, her maleficium depends upon her own sinful belief and not presumably upon the sins of her victims. ${ }^{62}$

A little more than a century later, Johann Nider developed and refined this idea in his own examination of the decalogue, the Praeceptorium. In a question devoted to the power of malefici to injure men, Nider argues that, with the devil's aid, they can cause harm to external things - to property, person, and reputation - but not to the soul. ${ }^{63}$ As proof he adduces standard exempla showing the power of the devil to torment Job and Anthony. Nonetheless, Nider insists that sinners are much more afflicted by magic than the good, both because the demons are defenseless before the power of the cross and because the devil has greater power over sinners. For this reason, Nider adds an important qualification to his explanation of image magic: when a witch strikes a man's image, "a demon invisibly harms the bewitched person in the same way, with God's permission, if the guilty person merited it." ${ }^{\prime 64}$ At the same time, though, the sins of the witches are relevant to Nider: when he asks why witches employ sacraments and other divine things in their magic, he responds that "as God is more gravely offended by men . . . the greater the power he gives to a demon over bad people. ${ }^{95}$ It is quite possible that the homines malos in this phrase are the witches themselves and not their victims, but regardless of his intentions it was easy to read Nider otherwise, as implying that a demon's power to do evil was at least in part a function of the magnitude of the witch's $\sin .{ }^{66}$ If so, witchcraft was understandable as a kind of economy of effort, whereby two sinners were punished at one time.

Writing not long after Nider, Martin of Arles developed and combined these ideas in his tract against witchcraft and superstition. Martin argues that just as God works miracles on account of Christian belief and faith, so false and evil beliefs lead God to permit bad things to happen. When God recognizes excessive adherence to vain observances, he allows the devil to give them efficacy: 
Just as true and Christian faith works miracles on those of good faith, so an evil and false belief, God permitting, sometimes works, or rather earns, misfortunes. For we have daily experience of people of bad faith whom God thus punishes on account of bad faith; indeed, God knows that some people adhere excessively to vain observances, permits some events to happen, and so, in consequence they are led to hold this belief even more strongly, so that their blindness becomes greater and they fall into the snare that they have made for themselves. ${ }^{67}$

So, the more superstitious people are, the more their superstitions seem well founded.

God, however, Martin suggests, does not restrict himself to punishing the individual sinner alone; sometimes he is so angered by sin that he punishes collectively, so that in profligate communities the good are punished along with the wicked. ${ }^{68}$ When a community is saturated with superstitious beliefs, God permits demons to punish that community collectively through witchcraft. Thus, Martin writes that

for the worthy flagellation and punishment of these crimes, God permits so many infirmities, pestilences, and storms, sterilities of the earth and of harvests, the death of cattle and beasts of burden to happen. ${ }^{69}$

This notion corresponds to a general tendency in late-medieval religion to look at both sin and salvation in collective terms: just as an individual's good works redounded to the credit of his confraternity, so his sins could bring punishment upon them all. ${ }^{70}$ And such punishment could be disturbingly severe. A popular exemplum in late-medieval sermons reported that after a drunken soldier knocked over the pyx with a beer pot, God's justice required that the entire region should be devastated. In the version of Johannes Herolt, a fifteenth-century Dominican preacher,

[the sea] passed beyond its bounds and flooded the land of many provinces, destroying villages and exterminating such a host of men that in all a hundred thousand perished. ${ }^{71}$

The destruction finally abated, though only after the specific sin responsible had been discovered and proper collective atonement had been made. If Jean Delumeau is right that "The Europeans who lived between the advent of the Black Death and the end of the religious wars had an acute sense of an accumulation of misfortune," then finding the source of such evils would be a pressing concern. ${ }^{72}$ The sin of witchcraft was in many ways the perfect explanation: heinous enough to warrant the most awful punishment and secret enough to exist anywhere, it enabled all the calamities of the world to rest on the shoulders of socially marginal women. 
Working from this established relationship between sin and retribution, late-medieval demonologists were gradually able to expand the limits of divine permission. Petrus Mamoris, like Martin of Arles, explains that the power of witchcraft depends upon the sins of the operators themselves:

for the execrations of the devil have efficacy among those who believe or adhere to such cursed diabolical machinations, or doubt and fret in some article of the faith, or wickedly desire to test, or from some wonder or curiosity want to try or to see, these maleficia, or to assist those who make them: all of which is dangerous to the faith. ${ }^{73}$

But, whereas for Martin the efficacy of witchcraft depends only upon ignorance and superstition, Mamoris is more liberal. He argues that magical harm could stem from either excessive credulity or excessive erudition, for while the former might lead to superstition, the latter leads to skepticism. ${ }^{74}$ Mamoris felt that not to believe in the power of witchcraft was as bad, and just as likely to incur punishment, as vana credulitas. Similarly, Nicholas Jacquier remarks that the devil was especially liable to injure skeptics through witchcraft:

Whence a few ignorant people boast very foolishly, asserting that they do not fear demons or witches, nor their witchcraft, unless the witches themselves personally approach those who are boasting after this fashion and administer some poisonous substance to them in their drink or food, whence they can be harmed. ${ }^{75}$

To Mamoris and Jacquier, witchcraft was not a problem largely confined to the rural lower classes: anyone (hypothetically) could be a witch, and anyone could be bewitched. This was especially true, if, as Jacquier argued, defenses which might be adequate against the devil alone, failed against witch and demon combined. Although the natural power of demons was sufficient to carry out any act of witchcraft, Jacquier maintained that demons were frequently prevented from the full exercise of their power by the ministry of good angels or by spiritual defenses in human hands. In such cases, however, witches could more easily approach their victims and do them harm, since under some circumstances divine permission was more liberal with respect to witchcraft than if the devil had acted directly. ${ }^{76}$

Institoris and Sprenger use these ideas about the relationship between divine permission and witchcraft in their own complicated model of misfortune. Once again, the authors foreground the active role of the witch at the expense of both God and the devil: in their view, sudden misfortune is almost always the result of witchcraft, and not the work of angels or demons alone. Their explanation for this is neither logically nor literally consistent: the degree of autonomy they allow to the devil, to the witch, and even to God, 
varies according to context, and they can devise no rule that is not immediately contradicted by exceptions. But, no matter: what counts is that they devise an explanation for the prevalence of witchcraft in the world which is consistent with conventional orthodox assumptions.

In good scholastic fashion, Institoris and Sprenger begin by considering the nature of misfortune analytically. Injuries, they maintain, are of four kinds: ministeriales (beneficial misfortune), noxiales (merited punishment), maleficiales (malicious harm, or witchcraft), and naturales (natural harm). ${ }^{77}$ Although these terms denote intentions or motives behind mischance, Institoris and Sprenger are really concerned with their agents: beneficial harm is the work of angels; merited injuries are carried out by demons, presumably under the supervision of God; natural injuries are due simply to natural causes, such as droughts caused by the motion of the stars and planets; and, finally, "Effects are said to arise from harmful magic when the devil works through witches and sorcerers."78

Maleficiales were of special interest because they were the most common and the most dangerous form of harm. Demons always prefer to work through the agency of witches, in part for the damnation of their souls, but more importantly because God permits them to do more harm through witchcraft than he would otherwise allow:

But because they seek to work through witches of this kind, in order to insult and offend the Creator and at the same time to bring about the loss of souls, knowing that in such a way, as God is more angered so he permits them more power to rage, and because innumerable acts of witchcraft are perpetrated which the devil would not be allowed to inflict on humans if he alone were working to harm people, but which the just, hidden judgment of God permits to be done through witches, on account of their perfidy and denial of the Catholic faith, accordingly such maleficia, by just judgment, are imputed secondarily to [witches], however much the devil might be the primary actor. ${ }^{79}$

Thus, witches are directly responsible for witchcraft, because it is their sin that gives the devil his power to injure in their name. In this way, Institoris and Sprenger carry the arguments proposed by earlier theorists to their logical conclusion: if God punishes men collectively on account of sin, and if the intensity of punishment is proportional to divine anger, then the more God is offended, the more he grants the devil latitude to harm the guilty and innocent alike. There is no sin more offensive to God than witchcraft, so maleficium itself provokes God to grant the devil permission to make it work: "just as because of the sins of the parents the innocent are punished, so now are many innocent people damned and bewitched on account of the sins of the witches. ${ }^{80}$ Demons could, of course, injure without the permission of the 
witch, but, because they were loath to do so, this happened only when they were specifically commanded by God to do so.

The mechanical nature of this conception of diabolic power is particularly evident in Institoris and Sprenger's discussion of superstitious methods of identifying a witch. Even practices which rely upon the implicit participation of the devil are reliable, they argue, because demons are prohibited from harming the innocent. Thus, if a devil is doing some witch's bidding in animal form and is wounded in process, it is the witch - and only the witch - who bears a corresponding wound.

For it is one thing to be harmed by the devil through a witch, and another to be harmed by the devil himself, without a witch. Because when the devil in the form of an animal receives blows, he then inflicts them upon another who is joined to him through a pact . . . Accordingly, he can harm only the guilty and those joined to him through a pact, and in no way the innocent. When demons seek to do harm through witches, however, then even the innocent are often afflicted, by divine permission, in revenge of so great a crime. ${ }^{81}$

Oddly enough, then, the limitations of demonic power could be reliably exploited to identify guilty witches, precisely because demons themselves are mere passive agents, strictly bound by the terms of their pacts with witches and subordination to God.

Through this argument, Institoris and Sprenger aligned the causes and agencies of misfortune to give the widest possible scope to witchcraft. Unfortunately, however well this model may have reflected contemporary fifteenthcentury conditions, it fits the traditional pattern of Christian beliefs quite poorly. For example, the inquisitors' argument becomes quite seriously muddled when they attempt to explain the trials of Job. The problem is that Job's afflictions were carried out by the devil in person; they were, then, noxiales and not maleficiales. But Job was also an innocent man, and when injuries happen to the innocent, they are maleficiales and not "merited." Some troublemaker must have asked for an explanation, for Institoris and Sprenger reply with open annoyance:

If, indeed, someone with too great a curiosity were to insist on knowing, just as often this material permits a strange insistence on the part of the defenders of witches, always lashing the air about the outer shells of words, and never penetrating to the marrow of truth, why Job was not persecuted by the effects of harmful magic through a demon, as he was by injuries. To these curious sorts it can be answered that Job was persecuted by the devil alone and not through the mediation of a male or female witch, either because this kind of superstition had not yet been discovered, or, if it had been discovered, then divine 
providence desired that the power of the devil be made known to the world, for the glory of God, as a warning of his plot. $^{82}$

Job, in the minds of the authors was clearly an exception: under normal circumstances, demons caused injuries only through witches, and usually had to do so if their victims were otherwise innocent.

This, then, was why witchcraft was so dangerous: God was so offended by the existence and practices of witches that he gave the devil more latitude to use his power for the affliction of men, affliction manifested in the magic of witches. This argument assumed that divine permission was a kind of sliding scale, automatically contingent upon circumstances: some actions, such as sin or the magic of witches, allowed greater applications of demonic power, others, such as prayer or Christian countermagic, allowed less. Hence, God's pervasive distaste for sex gave witches and the devil correspondingly greater power over human and animal sexuality. ${ }^{83}$ For this reason, witches characteristically destroyed fertility because such magic was more likely to work as planned than was weather magic or demonic obsession. Similarly, some species of maleficium were inherently less permissible, and were only efficacious if the victim was stained with sin. For example, although witches could make the penis of a sinner appear to vanish, they could not so delude anyone in a state of grace. ${ }^{84}$ Because God granted permission to harm according to these established rules (exactly as the devil participated in witchcraft), Institoris and Sprenger conceived of witchcraft as very much a personal duel between the witch and her victim, each trying through his or her actions to slide the scale of permission in his or her own favor.

Institoris and Sprenger held a view of the world that was both extremely mechanistic and highly anthropocentric. Because the beneficent power of God and the destructive power of the devil both functioned mechanically, the importance of the human operators who could successfully manipulate these powers was necessarily increased. Institoris and Sprenger also saw, however, that in the supernatural battle between witches and the Church, the Church was sadly overmatched: sacramental magic alone could not wipe out the scourge of witchcraft, only ameliorate its effects; to destroy witchcraft, it was necessary to destroy the witches.

\section{Notes}

1 Although it is dangerous to generalize about medieval folk-beliefs, evidence from modern and early-modern sources suggests a more or less consistent traditional European understanding of witchcraft and misfortune. See Gábor Klaniczay, "WitchHunting in Hungary: Social or Cultural Tensions?" in Klaniczay, The Uses of Supernatural Power, trans. Susan Singerman, ed. Karen Margolis (Cambridge: Polity Press, 1990), 167. For modern folk conceptions of misfortune, see Bente Gullveig Alver and Torunn 
Selberg, "Folk Medicine as Part of a Larger Concept Complex," ARV 43 (1987), 21-44; David Rheubottom, "The Seeds of Evil Within," in David Perkin, ed., The Anthropology of Evil (Oxford: Basil Blackwell, 1985), 77-91.

2 Rodney Needham, Primordial Characters (Charlottesville: University of Virginia Press, 1978), 31.

3 Salimbene de Adam, The Chronicle of Salimbene de Adam, ed. and trans. Joseph L. Baird (Binghamton: Medieval and Renaissance Texts and Studies, 1986), 640-1.

4 Ibid.

5 Augustine, City of God, 21.13, 990.

6 Ibid., 22.22, 1066.

7 Ibid., 21.14, 992.

8 Ibid., 1.9, 14-15.

9 Isidore of Seville, Sententiae, 1.1, c. 10, 17-18, in Lea, Materials, 1:69.

10 Gregory the Great, Morals on the Book of Job, ed. James Bliss (Oxford: John Henry Parker, 1844), 2.17.

11 Rather of Verona, The Complete Works of Rather of Verona, ed. and trans. Peter L.D. Reid (Binghamton: Medieval and Renaissance Texts and Studies, 1991), 1.8.

12 Athanasius, The Life of St. Antony, trans. Robert T. Meyer (Westminster, Maryland: The Newman Press, 1950), c. 9, p. 28.

13 Ibid.

14 Examples abound, but see especially Gregory the Great, Dialogues, trans. O.J. Zimmerman (New York: Fathers of the Church, 1959), 3.19.

15 Peter Damiani, De Castitate, 3.4, Patrologia Latina 145, 713.

16 Antonio Graf, The Story of the Devil, trans. Edward Noble Stone (New York: MacMillen, 1931), 97-8. See also Lea, Inquisition, 3:381-2; and Peter Dinzelbacher, "Der Realität des Teufels im Mittelalter," in Segl, Der Hexenhammer, 151-75. I have not been able to obtain the text of Ricalmus' book, the Liber Revelationum de Insidiis et Versutiis Daemonum adversus Homines; Dinzelbacher's reference is Bernardus Pezius, Thesaurus Anecdotorum Novissimus, I/2 (Augusta Vindelicorum [Augsburg], 1721), 373-472.

17 A suggestion of Edward Peters, who observes that for a monastic audience the terror of this devil was considerably mitigated by the formidable spiritual defenses which monks could deploy. For laymen and perhaps even secular clerics who were not so well fortified, the devil would then naturally appear as a relatively more threatening figure. Peters, 92-3.

18 Similarly, as the Church grew more inclusive after 1200, theological discourse began increasingly to reflect traditional popular beliefs. See Jacques Le Goff, "The Learned and Popular Dimensions of Journies in the Otherworld in the Middle Ages," in S.L. Kaplan, ed., Understanding Popular Culture (Berlin: Mouton, 1981), 31; and Alan Bernstein, "Theology between Heresy and Folklore: William of Auvergne on Punishment after Death," Traditio 38 (1982): 4-44; 5-6, and passim.

19 Thomas of Cantimpré, Bonum Universale de Apibus (NP: 1627) book 2, c. 57.3.

20 Giraldus Cambrensis, Itinerarium Kambriae, in Opera, vol. 6, ed. James F. Dimock (London: Longmans, Green, Reader, and Dyer, 1866), 1.12, p. 91.

21 For an in-depth study of Thomist theories of causation, see Francis X. Meehan, Efficient Causality in Aristotle and Thomas Aquinas, The Catholic University of America Philosophical Studies 56 (Washington, D.C.: The Catholic University of America Press, 1940).

22 Aquinas, Summa Theologiae, pt. 1, qu. 49.

23 Aquinas, Summa. Theologiae, pt. 1, qu. 49, art. 2.

24 "To the first point, it should be said that bad angels attack people in two ways. First, by inciting them to sin. In this they are not sent by God to attack people, but are sometimes permitted to do so according to God's just judgments. Sometimes, however, they attack men by punishing them, and in this they are sent by God." "Ad primum ergo, dicendum quod mali angeli impugnant homines dupliciter. Uno modo, instigando ad 
peccatum. Et sic non mittuntur a Deo ad impugnandum, sed aliquando permittuntur secundum Dei justa judicia. Aliquando autem impugnant homines puniendo. Et sic mittuntur a Deo.") Ibid., pt. 1, qu. 114, art. 1, ad. 1.

25 "Ad primum ergo dicendum quod non dicitur sic diabolus in homines potestatum habuisse, quasi posset eis nocere, Deo non permittente; sed quia juste permittebatur nocere hominibus, quos tentando ad suum consensum perduxerat." Ibid., pt. 3, qu. 49, art. 2. Lest one suppose that this situation has been somehow altered with Christ's passion, Aquinas immediately adds that, although Jesus has indeed provided a remedy to damnation, "the devil can still tempt men's souls and harrass their bodies." Ibid.

26 The growth of a more powerful, more terrible conception of the devil is discussed in Russell, Lucifer, 159-207 and passim; see also Russell, Witchcraft in the Middle Ages, 101-32, and Peters, 91-8.

27 For Augustine's own views on the powers of demons to inflict maleficia on a magician's behalf, see his refutation of Apuleius in City of God, 8.19, in which he asserts that "all the marvels of sorcery are achieved by means of the science taught by the demons and by their operations."

28 Rather of Verona, 1.10, 32-3.

29 Flint, 146-57.

30 Demons could not, for example, create real substances out of nothing or effect real transformations, although their powers over the human mind created illusions to this effect; many other marvelous things demons did by virtue of the natural characteristics of their spiritual bodies. Augustine, City of God, 18.18, 782-4.

31 Augustine, De Doctrina Christiana, 23.35; City of God, 10.10, 385.

32 See Lea, Materials, 1:143.

33 Burchard of Worms, Corrector, in Hanson, Quellen, 41.

34 Stephen of Lanskrana, provost of St. Dorothy's in Vienna, Himmelstrasse (1484). Quoted in Johannes Janssen, History of the German People after the Close of the Middle Ages, trans. A.M. Christie (New York: AMS Press, 1966), 16:231.

35 Augustine, City of God, 8.19, 325.

36 Hrabanus Maurus, De Magicis Artibus, Patrologia Latina 110, 1095-108.

37 See, for example, Thomas Aquinas, Expositio in Job, 1.3: "It should be understood . . . that with the permission of God demons can cause disturbances in the air, excite winds, and make fire fall from heaven" ("Considerandum est . . quod deo permittente daemones possunt turbationem aeris inducere, ventos concitare et facere ut ignis de coelo cadat"). All this, and much more, they did through the power of local motion which was natural to both good and evil angels.

38 "Cum enim innotuerit tibi, quanta cura sit sapientiae, et bonitati creatoris de hominibus, et rebus humanis, elucescet tibi evidenter, quia nec imaginibus, nec stellis, nec luminaribus, aut etiam coelis committit gubernationem eorum, nec eos exponit ullo modo voluntatibus magorum, aut maleficiis." William of Paris, De Universo, pt. 1, c. 46, in Opera Omnia (Paris, 1674; reprint, Frankfurt am Main: Minerva, 1963), 666.

39 "Nulla enim mulier speciosa incorrupta remaneret, nullus principum, nullus magnatum incolumnis persisteret si daemones malis voluntatibus hominum adesse et satisfacere permitterentur." Ibid.

40 Peter Brown, "Sorcery, Demons, and the Rise of Christianity from Late Antiquity into the Middle Ages," in Mary Douglas, ed., Witchcraft Confessions and Accusations (London: Tavistock Publications, 1970), 15.

41 "Magi sunt, qui vulgo malefici ob facinorum magnitudinem nuncupantur. Hi [permissu Dei] elementa concutiunt, turbant mentes hominum [minus confidentium in Deo] ac sine ullo veneni haustu, violentia tantum carminis interimunt... Demonibus enim adcitis audent ventilare, ut quisque suos perimat malis artibus inimicos. Hi etiam sanguine utuntur et victimis, et saepe contigunt corpora mortuorum ... Ad quos suscitandos cadaveris sanguis adjicitur. Nam amare daemones sanguinem dicitur. 
Ideoque quoties necromantia fit, cruor aqua miscetur, ut colore sanguinis facilius provocentur." Isidore of Seville, Etymologiae, De Magis, 8.9. Ivo of Chartres, Decreti, "De Incantoribus . . . "11.67, Patrologia Latina 161, 760-1.

42 "Hi permissu Dei elementa concutiunt, turbant mentes hominum minus confidentium in Deo ac sine ullo veneni haustu, violentia tantum carminis interimunt." Ivo of Chartres, loc. cit. The passage is headed "Ex dictis Augusti."

43 "Vere enim confitentibus et penitentibus nocere nequeunt malefici et divinatores, nec illudere eis qui spem suam ponunt in Deo, peccatoribus autem illudere solent, quia Deus, exigentibus peccatis, permittit." Jacques de Vitry, The Exempla of Jacques de Vitry, ed. Thomas Frederick Crane (London : David Nutt, 1890), no. 262.

44 Henry Suso, The Exemplar, ed. Nicholas Heller, trans. Ann Edward (Dubuque:The Priory Press, 1962), 5.2, p. 176. See also Richard Kieckhefer, Unquiet Souls: Fourteenth Century Saints and Their Religious Milieu (Chicago: University of Chicago Press, 1984), 5088.

45 See Larrisa Taylor, Soldiers of Christ: Preaching in Late Medieval and Reformation France (Oxford: Oxford University Press, 1992), 117-19, and as a good example, Jean Gerson, De Erroribus circa Artem Magicam, in Oeuvres complètes, ed. Palemon Glorieux (Paris: Desclee, 1969), 7:80.

46 Heiko Oberman, "The Shape of Late Medieval Thought: The Birthpangs of the Modern Era," in Oberman, The Dawn of the Reformation: Essays in Late Medieval and Early Reformation Thought (Edinburgh: T. \& T. Clark, 1986): 18-38; 27.

47 Gordon Leff, The Dissolution of the Medieval Outlook (New York: Harper and Row, 1976), 57-9; Francis Oakley, Omnipotence, Covenant, and Order (Ithaca: Cornell University Press, 1984), 80-1.

48 Leff, 29, 76-7.

49 "quod nulla causa agit immediate ad effectum aliquem in passo nisi naturaliter ordinata ad illum producendum.” Samuel de Cassini, Questio Lamiarum, in Hansen, Quellen, 266.

50 Ibid., 267, 264.

51 "Quandoque talia permittit, in poenam correctionis peiorum, quandoque in tentationem augmentandorum meritorum, quandoque in prodigium futurae gratiarum actionis." Ulrich Molitor, Tractatus de Pythonicis Mulieribus, in Institoris and Sprenger, Malleus Maleficarum (Frankfurt am Main, 1580), 695, 712-13.

52 "Ita ut huiusmodi plagam praenoscit futuram, ex tunc commovet mentes huiusmodi Malckiesarum mulierum, aliquando eisdem persuadendo: aliquando ob invidiam, quam tales sceleratae mulieres adversus proximum gerunt, in vindictam mouendo easdem sollicitat, quasi ipsas mulieres doceat huiusmodi tempestates, et aeris turbationes prouocare." Ibid., 698.

53 Ibid. Molitor was equally skeptical of Aquinas's theory that incubus demons could sire human children with stolen semen. Ibid., ch. 10.

54 Jean Vincent, Liber adversus Magicas Artes et eos qui dicunt artibus eisdem nullam inesse efficiam, in Hansen, Quellen, 229.

55 "Vbi autem homines credunt ista maleficia effectualiter fieri: ibi reperiuntur plures malefici: nec possunt extirpari igne et gladio, quia quanto diligentius huiusmodi persecutio fit: tanto plus crescit delusio. Nam persecutio arguit quod diabolus plus timetur quam deus: et quod possit medio malorum mala ingerere, et demum placatur diabolus qui sic timetur: et sic optinet intentum." Nicholas of Cusa, Opera (Paris, 1514; facsimile reprint, Frankfurt am Main: Minerva, 1962), vol. 2, bk. 9, fol. 172.

56 Other skeptics had similar qualms. See for example the echoes of William of Paris in work of the sixteenth-century Florentine Jurist, Gianfrancesco Ponzinibio, who argues that although witches might injure men through their maleficium, their power to do harm was strictly limited since otherwise all men might seem to be in the hands of demons, which since the advent of the Savior was certainly not true. Tractatus de Lamiis et Excellentia Juris Utriusque, in Paulus Grillandus, Tractatus de Sortilegiis (Frankfurt am Main: 1592), 279. 
57 "Ad quod respondent praedicti quod hoc est ex permissione divina: sed sic respondere ridiculum est, quoniam nihil fit in mundo quod Deus fieri non permittat, sive bonum sit, sive malum." Mamoris, 12.

58 "Diabolus potest de facto hominem localiter movere (permittente deo) ad maleficium perpetrandum adque obscenos actus explendos. Permissio divina in ista conclusione intelligitur negative."Vincente Dodo, Apologia, in Hansen, Quellen, 277.

59 "Mala enim que nostris exigentibus [peccatis] in mundo fiunt, deus velut per suos tortores iuste per demones solet infligere," quoting Nider, Formicarius, 5.4 (who supplies the missing peccatis). Malleus, pt. 2, qu. 1, ch. 15, p. 145. Similarly, "punishments are often brought about through the ministry of demons," (sepius tamen ista ministerio demonum exercent), pt. 1, qu. 1, p. 11.

60 "Et idcirco magi nequeunt turbare mentes bonorum qui talia non credunt, sed mentes infidelium et malorum." Guillermus Vorillongus, Super Quatuor Libris Sententiarum, dist. 34, in Lea, Materials, 1:167.

61 Robert of Brunne, Handlyng Synne, ed. F.J. Furnivall (London: Early English Text Society, 1901), ln. 544 6, p. 20. The treatise is an English translation of William of Wadington's Manuel des Pechiez; this exemplum, however, was an addition of Robert's own, and replaced one of Gregory the Great's tales.

62 The bishop's perfectly understandable, if illogical, response was that the witch should at once cease to believe in her magic.

63 Nider, Praeceptorium, 1.11, y.

64 "Invisibiliter demon maleficiatum hominem eodem modo ledit dei permissione si demeruit reus." Ibid., v.

65 "Secundo ut deus sic grauiter per homines offensus . . . demoni maiorem potestatem in homines malos tribuat." Ibid., z.

66 Later witch-theorists, such as Martin of Arles discussed below, certainly did so.

67 "Quod sicut vera et Christiana fides mirabilia operatur in bene credentibus, sic mala et falsa credulitas, Deo permittente, euentus malos interdum operatur, vel potius demeretur. Nam experimus quotidie in male credulis, quos ita Deus punit propter malam fidem, imodum $[s i c]$ cognoscit Dominus nimium adhaerere aliquibus vanis obseruantiis, permittit aliquos euentus contingere, et ita eos plus consequenter firmari in tali opinione, ut maior fiat caecitas eorum, et in laqueum cadant, quem sibi fecerunt." Martin of Arles, Tractatibus de Superstitionibus, printed in Jacquier, 437.

68 See Augustine, City of God, 1.9.

69 "Quod ad dignam flagellationem et punitionem horum flagitiorum permittit Deus tot infirmitates, pestilentias, et tempestates, sterilitates quoque terrae, nascentium fructuum, et interitum pecorum et iumentorum euenire." Martin of Arles, 438. Martin's views were not unique: St. Bernardino of Siena, for example, announced in a sermon that "Another sin which derives from pride is the sin in regard of charms and of divinations, and because of this God many times doth send his scourges into cities." See Bernardine of Siena, Sermons, ed. Nazareno Orlandi, trans. Helen Josephine Robins (Siena: Tipografie sociale, 1920), 26.2, p. 165.

70 For the importance of community to late-medieval conceptions of salvation and latemedieval religion in general, see A.N. Galpern, "The Legacy of Late Medieval Religion in Sixteenth Century Champagne," in Charles Trinkhaus and Heiko A. Oberman, eds, The Pursuit of Holiness in Late Medieval and Renaissance Religion (Leiden: E.J. Brill, 1974), 141-76; and John Bossy, Christianity and the West 1400-1700 (Oxford: Oxford University Press, 1985), 35-75.

71 Johannes Herolt, Miracles of the Blessed Virgin (1435-40), trans. C.C. Swinton Bland (London: George Routledge and Sons, 1928), c. 10, pp. 27-9; the exemplum is a retelling of Caesarius of Heisterbach, 7.3, although with a new moral: "From this may be seen that sometimes the whole community is punished for the fault of one."

72 Jean Delumeau, Sin and Fear: The Emergence of a Western Guilt Culture, 13th-18th Centuries, trans. Eric Nicholson (New York: St. Martin's Press, 1990), 302. 
73 "Nam apud illos diabolicae execrationes efficaciam habent qui credunt vel adhaerent talibus execratis machinationibus diabolicis, vel dubitant et formidant in articulo fidei, vel experiri nequiter volunt, vel ex quadam admiratione seu curiositate volunt hec maleficia tentare, sive videre, vel facientibus assistere: quae omnia sunt periculosa in fide.” Mamoris, 58.

74 Ibid., 31.

75 "Unde valde stulte se iactant nonnulli ignari, asserentes, se non timere Daemones vel maleficos, nec eorum maleficia, nisi malefici ipsi appropinquantes personaliter huiusmodi se iactantibus aliquam rem venenatam eis ministrauerint, in potu vel cibo, unde laedi possint." Jacquier, 93.

76 Ibid., 111, 117. Perhaps because in Jacquier's mind, a witch's maleficium resembled a kind of poison, against which supernatural defenses might prove unreliable.

77 Malleus, pt. 1, qu. 2, pp. 15-16.

78 "Et Maleficiales effectus dicuntur quando demon per maleficos et per magos operatur." Ibid., 16.

79 "Sed quia in contemptum et offensam creatoris simul et in perditionem animarum querunt huiusmodi per maleficas exercere scientes quod per talem modum sicut deus amplius irritatur ita et amplius permittit eis potestatem seuiendi; quia et de facto innumera malificia perpetrantur que non permitterentur diabolo inferre hominibus si per se solum affectaret homines ledere que tamen permittuntur iusto et occulto dei iudicio per maleficas propter perfidiam et catholice fidei abnegationem. Unde et eis iusto iudicio talia maleficia imputantur secundario quantumcunque diabolus sit actor principalis." Ibid., pt. 2, qu. 1, ch. 11, pp. 131-2.

80 "Unde de sicut innocentes puniuntur ex culpis parentum, ita et iam plures innoxii damnificantur et maleficiuntur propter peccata maleficorum.” Ibid., pt. 1, qu. 14, p. 71. This is a curious argument, and the authors admit that it is not for everyone: they advise preachers, for example, to explain misfortune with a simpler, if still unsatisfying proposition: "Sine culpa nisi subsit causa non est aliquis puniendus." Ibid., 76.

81 "Quia aliud est a demone per maleficam ledi, et aliud per ipsum demonem absque malefica, quia demon per se in effigie animalis tunc verbera suscipit quando alteri sibi per pactum coniuncto infert. [Et quando cum eius consensu ad talem apparitionem sub tali forma et modo se ingessit.] Unde sic tantummodo noxios et sibi per pactum coniunctos nocere potest et nullo modo innocentes. Per maleficas autem ubi demones ledere querunt tunc etiam innocentes permissione diuina in ultionem tanti criminis sepe affligunt." Ibid., pt. 2, qu. 1, ch. 9, p. 124.

82 "Si quis vero curiosius insistaret sicut plerumque hec materia curiosas patitur a maleficarum defensoribus instantias: semper in cortice verborum aerem verberantes et medullam veritatis numquam penetrantes. Cur Job non maleficiali effectu per demonem sicut noxiali percussus fuit. His curios[is] etiam responderi potest quod Job fuit percussus a diabolo solum et non mediante malefico vel malefica. Quia hoc genus superstitionis vel nondum erat inuentum vel si erat inuentum diuina tamen praeuidentia voluit ut potestas demonis mundo ad precauendum eius insidias pro dei gloria innotesceret." Ibid., pt. 1, qu. 2, p. 16.

83 "Plus permittit deus super hunc actum per quem primum peccatum diffunditur quam super alios actus humanos." Ibid., pt. 2, qu. 1, ch. 6, p. 114. Although to modern readers this makes very little sense, Institoris and Sprenger apparently assumed that God's motives in this case would be so obvious as to require no further explanation.

84 This protection, however, extended only to the perception of the just of their own bodies: although the devil could not delude them into believing that their own bodies had been mutilated, he could still deceive them with illusions of absent penises in others. Ibid., pt. 2, qu. 1, ch. 7, p. 117. 